\title{
Policy Analysis of Teacher Professional Improvement in YPPSB Elementary School
}

\author{
Sismanto \\ Islamic University of Malang, Indonesia \\ *e-mail: sirilwafa@gmail.com
}

\begin{abstract}
Article Information
Received: November 25, 2020

Revised: December 23, 2020

Accepted: December 24, 2020

Online: March 03, 2021
\end{abstract}

\section{Keywords}

policy, teacher professional, YPPSB elementary school

\begin{abstract}
The purpose of the research was to identify policy formulation, policy implementation, policy environment, and teachers' performance professional improvement in YPPSB elementary school. This policy research used a qualitative approach. The data of this research was collected by in-depth interviews, observation, documentation study. Analysis of data using a technique of organizing data, coding, verification, and conclusions). This research's findings are as follows: (1) policy of the teacher professional improvement of YPPSB Elementary School - PT. Kaltim Prima Coal follows a Top-down approach and bottom-up approach model of formulation policy, (2) the implementation of teacher professional improvement policy successfully conducted to its vision, mission, and goal; (a) recruitment of qualification teachers, (b) Conducting and includes teachers in the education and training, (c) professionalization of teachers through KKG and MGMP, (d) facilitating teachers to continue their studies $S 2$, (e) educational supervision, ( $f$ ) course intensification, $(g)$ weekly meeting, (h) reward, and (i) allowance. Policy recommendations that can be given are as follows, (1) Principal of YPPSB Elementary School needs to increase teachers' professional development, primarily through forms of training, (2) the Education Department to develop comprehensive education, especially for private schools, and (3) The Government continually strive to find alternatives to increase the professionalism of teachers.
\end{abstract}

\section{INTRODUCTION}

The government's efforts to improve Indonesia's quality of education in elementary schools deserve appreciation from Elementary School (SD) and Madrasah Ibtidaiyah (MI). One of them is the issuance of the Sikdiknas Law, characterized by school-based management and is affirmed in government regulation on National Education Standards, including various educational standards, including educators' standard education personnel. Education is determined by all education components, such as teachers' quality, equity, curriculum, adequate facilities and infrastructure, and a conducive PBM atmosphere, supported by government policies. Teacher quality is a must for educational institutions/schools through a fair teaching process.

However, based on data on the power of school principals and teachers at the primary and secondary education levels in 2015/2016, which refer to educational indicators, the results show that the number of educators and school principals at the basic education level is eligible to teach or have a bachelor's degree or diploma 4 . only $84,82 \%$. 
It shows that there are still $15.18 \%$ of educators and school principals who are not fit to teach (Kemendikbud, 2016). It is supported by the results of research findings by (Setiawan et al., 2017), which show that the competency test scores for elementary and junior high school teachers in 2013 by taking the background in Batubara district as a national average are still shallow, moreover there are still test results. Teacher competence, the competency score is 1.0.

A teacher is said to be a professional if he does not just understand his knowledge, learning materials, and methods. However, a professional teacher is required to motivate students, have great competence, and broaden knowledge of the world of education. A professional teacher must also have in-depth competence about the meaning of life in life as citizens and society to understand teachers' work patterns and loyalty as an educator to their profession. In line with the demands of the law. National Education System article 40, paragraph 2 a, that in implementing the process of teaching and learning activities, a teacher is required to increase the enthusiasm for learning of his students through the class organization, classroom culture, and meaningful teaching.

Concerning learning activities, the teacher's achievement of learning objectives is determined as one factor that needs to be appreciated and get adequate attention in terms of the mandated task and its position in the school structure. Teachers are the spearhead of education who give color to the teaching and learning process activities and education quality. (Supriadi, 2009) in his research findings suggests that professional teachers are one of the critical components of education quality. Professional teachers can deliver learning effectively and efficiently to students following the barriers in their teaching environment. However, creating a professional teacher is not an easy task. It is more so for school institutions tasked with improving and developing knowledge, especially regarding professional teachers' improvement.

Increasing and developing teacher professionalism requires a healthy work climate so that teachers can develop personally and reliably. Teacher involvement plays a role in a hierarchical structure and psychological involvement so that teachers feel recognized, responsible, and feel they have a complete sense of belonging to the school. As educators, teachers have a strategic position, and teachers directly influence student teaching and learning activities. In turn, the learning outputs are determined by the quality of the meetings between teachers and students (Pălășan, 2015).

Given teachers' strategic position in learning, special requirements, and professional expertise, competencies with various capacities are needed. (Kotten, 2005) formulates that professional teachers have at least four main criteria as a teacher, including (1) professional competence, (2) time for professional activities (time devotion), (3) adequate rewards for work (professional rent), and (4) a professional business (professional effort). Departing based on the above, policy research is needed to provide strategic policy solutions so that teachers become qualified, professional, productive, and have a tremendous commitment to educational development.

\section{METHODS}

This research is a policy study in educational institutions/foundations under the auspices of companies engaged in coal mining, PT. Kaltim Prima Coal. This research was conducted at the Prima Swarga Bara Education Foundation (YPPSB) as one of PT's elementary schools. Kaltim Prima Coal.

The period of study for field research is five months, from September to October 2020. The formulation of policy analysis is carried out using:

1. formulating problems that provide information on conditions that give rise to educational policy problems,

2. predicting or predicting policies to produce logical consequences about future information from the implementation of alternative educational policies,

3. providing information recommendations about the value and usefulness and consequences from a solution to educational problems in the future,

4. evaluation and assessment that produces information about the impact of implementing alternative education policies in the present and the future.

However, this study focuses on the policy process (Nugroho, 2009); the policy process starts with formulation, policy implementation, and policy evaluation to improve policy performance. 


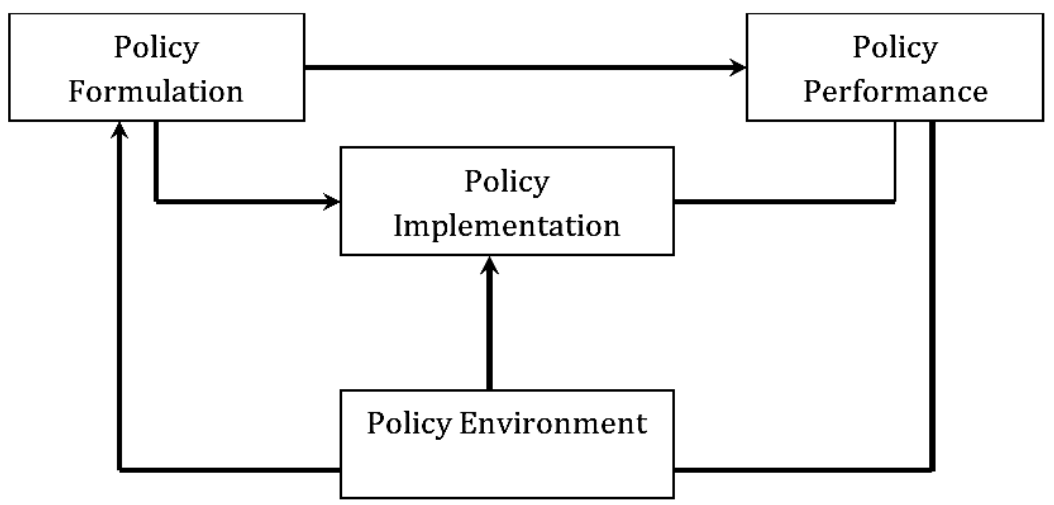

Figure 1. The policy process, according to Nugroho (2008)

This research is a policy study (policy research). Policy research is a specific process aimed at providing policymakers with the choices and information they need to solve the problems they face today (Majchrzak et al., 2014). Policy research here is research on policy (studies of policy process) by focusing on research on the policy process that includes policy formulation, implementation, environment, and policy performance (Nugroho, 2009). Therefore, researchers are not directly involved in policy design, implementation, monitoring, and policy evaluation. However, conducting observations, interviews, and recording documentation, archives, and statistics data relating to teacher professional development policies at YPPSB Elementary School Sangatta. Given this research has characteristics; (1) the focus is multidimensional, (2) uses an empirical induction assessment orientation approach, (3) deals with the future and the past, (4) responds to research users, and (5) relates to values, it is very appropriate if research It uses policy research following (Majchrzak et al., 2014) policy research formulations and approaches appropriate research is qualitative (Taylor et al., 2016).

The data collection technique for policy research uses a qualitative approach: participant observation, in-depth interview, and documentation review. Data collected from key informants (essential information). The critical information referred to is the education manager, principal of YPPSB elementary school. Other data sources come from the vice-principal, several teachers, and administrators (Denzin et al., 2018). Policy research that uses a qualitative approach, data analysis that researchers in analyzing data can take are (1) data organization, by arranging each data according to the chronology of its activities in a systematic manner, (2) determining categories by the coding focus of research, (3) sorting data by coding each topic that has been organized on field note sheets, (4) formulating provisional findings conclusions at each research focus, (5) conducting verification through repeated data reduction and conformity with data presentation, and (6) drawing the final findings, previously verified through data validity testing techniques on preliminary findings (Matthew B. Miles, et al., 2014). Checking the validity of the findings is an important step. In qualitative research, the validity of the data is determined by four criteria used as the basis for obtaining convincing findings: credibility, transferability, dependability, and confirmability (Moleong, 2002).

\section{RESULTS}

Formulating teacher professional development policies at YPPSB elementary school is systematically designed as a strategic planning model that makes decisions through consultative, participative decisions. To take advantage of strengths and opportunities, reduce weaknesses and threats, and achieve the results during the next one to five years. This policy model's benefit is that a teacher professional development policy model can be adapted to other schools. Implementing the policy to increase teacher professionalism was carried out at YPPSB elementary school using a top-down approach and a bottom-up approach through program implementation.

The policy environment determines the implementation of policies to increase teacher professionalism at YPPSB elementary school, the school principal's leadership, teacher resources, the committee's active role, and support for the external environment. The performance of policies to increase teacher professionalism has increased school pride in the title Adiwiyata School 2010, non- 
academic and academic achievements at the local, regional, and national levels.

\title{
DISCUSSION
}

\section{Policy Formulation for Teacher Professionalism Improvement}

The development of teacher professionalism is an effort to help teachers who do not have reliable qualifications become highly qualified. Thus, increasing teachers' professional competence is an encouragement or sharing opportunities for these teachers through programs and activities that the government is trying. On the one hand, the impetus for professionalism is only a boost, so that the more active one is the teacher himself. That is the teacher who should ask for support from the authorities in coaching. The encouragement given is also reliable encouragement aimed at fostering the development of teacher professionalism. (Senduk, 2008) emphasizes that the right policy formulation has at least seven steps that must be taken, namely: (1) identification of existing policies, (2) environmental situation analysis, (3) analysis of sources of funds and resources owned, (4) ) capability gap analysis, (5) identification of various policy alternatives, (6) assessment of various alternatives, and (7) determining the most appropriate strategy. It is in line with the following research findings:

\begin{abstract}
"The formulation of an appropriate and realistic education policy and also based on a strong concept. The formulation of policies used is in line with the vision, mission, and formulate policies increasing teachers' professionalism using two ways: the top-down approach and bottom-up approach. The approach used by the principal to formulate policies to increase teacher professionalism top-down and bottom-up approaches are used. The principal in formulating a plan to increase teacher professionalism uses two approaches, namely the upstream approach and the downstream approach."
\end{abstract}

This study's findings indicate that the formulation of teacher professional development policies at YPPSB elementary school is systematically designed to take advantage of strengths and opportunities, reduce weaknesses and threats, and achieve the results during the next five years. The strategic plan contains a realistic vision, mission, goals/objectives, and programs. It is also a planning document for YPPSB elementary school education, referred to as "strategic plan," a five-year plan that describes the vision, mission, goals, strategies, programs, and activities of YPPSB elementary school contained in the annual operational plan. Determining the formulation of teacher professional development policies at YPPSB elementary school has gone through implementing a policy formulation that characterizes a blend of personal, group, and participatory consultative models. Decision making to formulate the policy formulations taken by the principal of YPPSB elementary school started from understanding the mandate of the Foundation (YPPSB), which was integrated with the vision and mission of YPPSB elementary school, opening teacher rooms for dialogue, discussion, gathering information, and discussing the formulation of policies for the professional development of teacher enthusiasm.

Top-down and bottom-up approaches are used for policy formulation. Top-down approaches, for example, the chairman of the foundation, education manager, business \& support manager, and the main conveying ideas than at the bottom, accept and implement them. While the bottom-up approach, for example, the formulation of policies carried out were suggestions from subordinates and implementing units in YPPSB elementary school, then formulated and discussed at school level meetings, work meetings, and more. Whereas the bottom-up approach, for example, the school leadership, fully submits the implementing unit's head to make school education planning, besides, the school leadership in preparing education planning always absorbs aspirations or input from subordinates. According to (Mayang Sari 2008), a bottom-up approach is an approach in which the initiative to formulate a strategy is taken by sharing organizational units or divisions, then conveyed to the top. This approach will get a combination of plans proposed by each unit. The weakness of this approach is that the plans made are only the goals of each unit. While the top-down approach is an approach in which the initiative to formulate strategies is taken by the executive at the organizational level, who formulates an integral and coordinated strategy, usually by looking at the leaders at lower levels. This strategy was comprehensive, then used to set targets and evacuate the work of each unit. Determination of National Education Standards mentioned several competencies of teacher professionalism at the primary and secondary education levels and early childhood education, including social, pedagogical, personality, and 
professional competencies as stated in Government Regulation No. 19 of 2005. Pedagogic competence is teachers' expertise in managing students, including descriptions to students, design, implementation, assessment of learning outcomes, and student development to hone their various abilities. Personality competence is related to a stable, wise, and dignified character, an example, and a noble character. Professional competence is the teacher's expertise in making extensive and in-depth learning modules that guide students in meeting the set competency standards. Social competence is a feature of individual attitudes related to self-concept that cannot be separated from the social area and achieve efficient social interaction. Social competence includes interactive skills and solving social life problems.

\section{Implementation of Teacher Professionalism Improvement Policies}

The development of teacher professionalism is an effort to help teachers who do not have reliable qualifications become reliable qualifications. Thus, teachers' professional skills encourage or share these teachers' opportunities through programs and activities from schools and the government. On the one hand, the encouragement of professionalism is not just a push, so that the more active one is the teacher himself. (Kotten, 2005) requires that professional teachers have two characteristics, namely a high level of expertise and commitment. Increasing teacher professionalism can be tried by preparing teachers in pre-service training, teacher professional development (in-service training), increased dedication and spirit of professionalism, and increased appreciation and welfare.

The pattern of teacher professional development as a manifestation of teacher professional development is the same. Close ties between schools and teacher coaching, increased recruitment of prospective teachers, upgrading programs related to field applications, education level of prospective educators, implementation of supervision, quality of learning management based on total quality management, linking the concept of link and match, empowering reading and supporting learning equipment, citizen recognition of the teaching profession, and professional competence by providing decent welfare (Supriadi, 2009). The operational decisions regarding implementing teacher professional development policies at YPPSB elementary school are based on the Prima Swarga Bara Education Foundation's blueprint. This policy is then implemented in strategic planning. Based on research into the implementation of teacher professional development policies, namely, strict teacher recruitment following their qualifications and competencies, involving teachers in training, the professionalization of teaching staff through grouping teacher (KKG and MGMP), facilitating teachers who are continuing S2 studies, supervising education, intensifying courses, weekly meetings, providing rewards / increasing incentives and benefits for school personnel, and achievement allowance programs. To further clarify how the implementation of teacher professional development policies carried out at YPPSB elementary school schematically can be seen in the following picture:

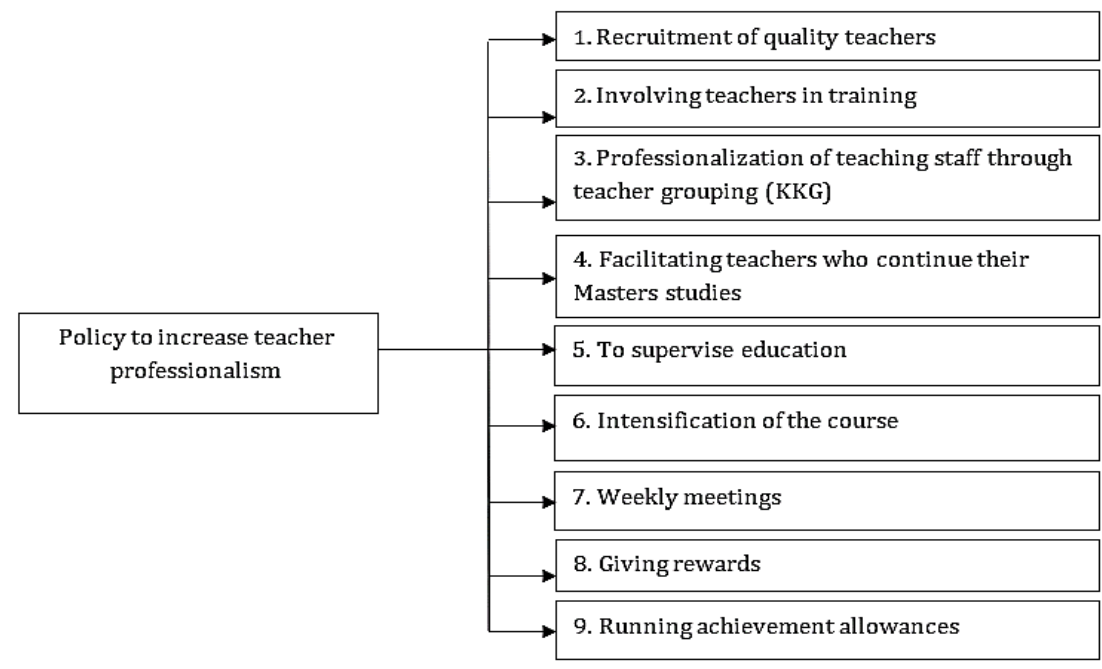

Figure 2. Implementation of Policies for Increasing Teacher Professionalism at YPPSB Elementary School 
Interesting findings found by researchers in the field are related to policies to increase teacher professionalism. Foundations provide several allowances and benefits: basic salary, religious holiday fiance, educational service allowances, service allowances, YPPSB pension program, transport assistance, leave money, Jamsostek program, inpatient and outpatient medical expenses, replacement of glasses and lenses. Based on empirical data with descriptive analysis, process, and evaluative analysis, it is found that the institutional model for implementing teacher professional development policies is to combine top-down and bottom-up approaches. This finding is supported by the opinion of (Mayang Sari 2008) that this planning is developing a strategy carried out by policymakers to integrate planning and evaluation. The institutional model for implementing teacher professional development policies is described as follows:

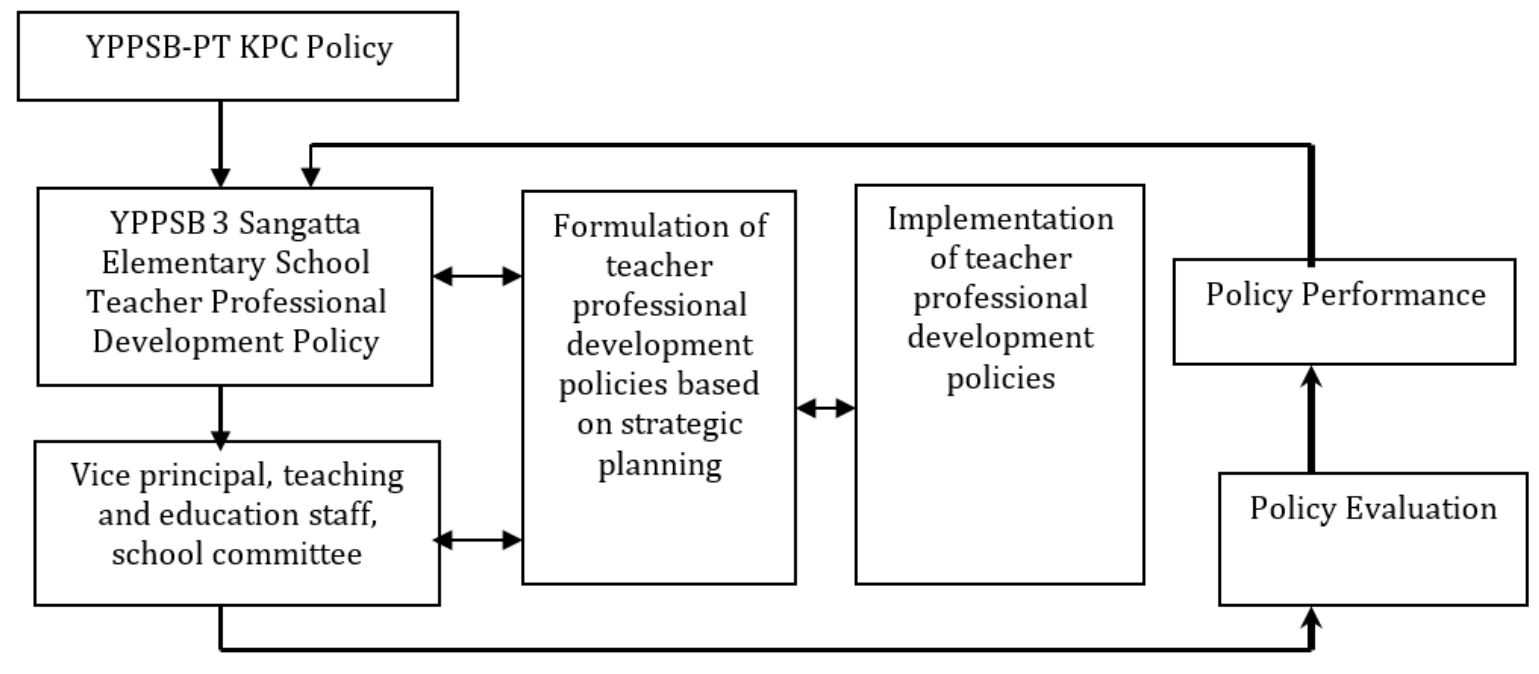

\section{Figure 2. Modification of the implementation of the YPPSB Elementary School teacher professional development policy}

The school principal determines the implementer and resources, while in the operational plan, the head of the wall is delegated to the principal as the implementer of teacher professional development policies.

\section{Teacher Professionalism Development Policy Environment}

The research findings found several crucial factors that indicate teacher professional development policies at YPPSB elementary school. This policy analysis is guided by in-depth interviews and documentation reviews that include the school principal's leadership, teacher resources, and school committees. The research findings show that the school leader's role as a determinant of direction has made a clear vision, mission, and goals in the policy environment. The YPPSB elementary school principal's leadership strength lies in the vision, mission, and policy planning formulated with school members, carried out during annual work meetings and weekly meetings. It is marked by the formulation of the vision, mission, and goals. However, the vision, mission, and objectives are written on paper and must be translated into strategic, long-term, and short-term program plans to meet internal needs and anticipate the external environment.

The leadership that is being carried out by the principal of YPPSB elementary school as a policy environment is in line with the opinion of (Ariyani 2017) that the increase in teacher professionalism carried out by the principal's leadership is based on the results of his research, namely: (1) compiling a school vision, (2) creating an understanding of what will be changed, where the school is directed, and how to do it, (3) creating a planning process that can capture learning that focuses on improving teacher professionalism. The school's internal environment also influences the policy environment for increasing teacher professionalism at YPPSB elementary school. Based on the research findings, the school's partnership with the school committee in implementing policies to increase teacher 
professionalism has been implemented. The school committee's strategic position is a consultative institution and has become a counterweight to school management.

The school's external environment also influences the conducive policy environment for increasing teacher professionalism at YPPSB elementary school. The external environment includes competitions, dissemination, seminars, and training held by institutions outside of school, for example, National Learning Innovation (Isobel), Indonesian Teachers Conference (KGI), Archipelago Teachers Conference (KGN), Education Office of East Kutai District, and East Kalimantan Province, and the Ministry of National Education. The Indonesian Teachers Conference (KGI) and the National Teachers Conference (KGN) were not wasted by YPPSB elementary school to send representatives to the conference. Meanwhile, the education office provides guidance, and the national education ministry makes policies that increase teacher professionalism, for example, teacher certification.

\section{Teacher Professionalism Improvement Policy Performance}

The formulation of policies for improving teacher professionalism at YPPSB elementary school is based on a strategic plan model and integrates top-down and bottom-up approvals so that its implementation generates pride for teachers and schools. The policy performance in question is the performance in the field of school achievement. These findings indicate a definite source of funding from PT. Kaltim Prima Coal, BOS, and BOSDA, then the performance of the policy to increase the professionalism of YPPSB elementary school teachers resulted in policy performance achievements, below:

Table 1. National Exam Score (NUN) in 2010-2011 of YPPSB Elementary School

\begin{tabular}{lcc}
\hline Subject & Highest Score & Average Score \\
\hline Indonesian & 9.60 & 8.54 \\
Mathematic & 10.00 & 8.04 \\
Science & 9,75 & 8.68 \\
\hline
\end{tabular}

Table 2. The final exam scores for class VI in 2018-2019 of YPPSB Elementary School

\begin{tabular}{lcc}
\hline Subject & Highest Score & Average Score \\
\hline Indonesian & 9.60 & 7,81 \\
Mathematic & 10.00 & 7,26 \\
Science & 9,75 & 7,37 \\
Religion & 9,60 & 8,65 \\
Civic & 9,60 & 8,19 \\
Social science & 10.00 & 7,76 \\
cultural arts and crafts & 9.75 & 7,88 \\
Physical Education & 10.00 & 8,06 \\
English & 10.00 & 7,85 \\
ICT & 10.00 & 7,84 \\
\hline
\end{tabular}

According to the table above, Judging from the academic dimension, YPPSB elementary school has completed $100 \%$ of its students. The results of the National Exam Score (NUN) in 2018-2019, the highest score in Indonesian subjects was 9.60 with an average of 8.54 , the highest score in mathematics was 
10.00 with an average of 8.04 , the highest score in science subjects was 9,75 with a mean of 8.68. for the final examination scores for class VI, 2018-2019 in the subjects tested, namely: Indonesian, mathematics, science, religion, Civics, Social Sciences, Cultural Arts and Crafts, Physical Education, English, ICT, respectively 7.81, 7.26, 7.37, 8.65, 8.19, 7.76, 7.88, 8.06, 7.85, 7.84.

Apart from that, it can be seen from the resources and performance of YPPSB elementary school. For national, regional, and local scales, the performance of policies to increase professionalism also shows a proud performance, namely, (1) national scale; (a) national dedicated teacher finalists (2019), (b) national learning innovation competition finalists (2017), (c) teacher writing competition finalists in 2007, (d) library performance competition finalists, 2010, (e) Adiwiyata school 2010. (2) regionalscale; teacher competition, poetry reading competition, choir competition, poetry writing competition, spelling bee competition, cluster competition. Moreover, (3) achievements at the level of East Kutai Regency; creativity competition in skills, creativity competition in arts, poetry reading competition, storytelling competition, outstanding teachers, storytelling competition, walking competition, quiz competition in the field of study.

\section{CONCLUSION}

The discussion above guides the author in providing conclusions:

1. Formulation of policies to increase teacher professionalism at YPPSB elementary school uses strategic planning that makes decisions through consultative, participative decisions.

2. The implementation of the policy to increase teacher professionalism carried out at YPPSB elementary school using a top-down approach and a bottom-up approach through program implementation, including (1) strict teacher recruitment according to their qualifications and competence, (2) involving teachers in training, (3) professionalization of teaching staff through teacher grouping (KKG), (4) facilitating teachers who continue their Master's studies, (5) supervising education, (6) intensifying courses, (7) weekly meetings, (8) giving rewards / increasing incentives and school personnel benefits, and (9) running a performance allowance program

3. The policy environment determines the implementation of policies to increase teacher professionalism at YPPSB elementary school, the school principal's leadership, teacher resources, the committee's active role, and support for the external environment.

4. The performance of policies to increase teacher professionalism has increased school pride in the title Adiwiyata School 2010, non-academic and academic achievements at the local, regional, and national levels.

\section{REFERENCES}

Ariyani, R. (2017). Kepemimpinan Kepala Sekolah dalam Pengembangan Profesionalisme Guru. Jurnal Al-Afkar, 5(1), 107-128. Retrieved from http://ejournal.fiaiunisi.ac.id/index.php/alafkar/article/view/135

Denzin, N. K., \& Lincoln, Y. S. (2018). The SAGE Handbook of Qualitative Research (Fifth Edition). SAGE Publications, Inc. https://doi.org/10.1007/s11229-017-1319-x

Kemendikbud. (2016). Analisis Sumber Daya Manusia Pendidikan Dasar dan Menengah 2015/2016. Pusat Data dan Statistik Pendidikan dan Kebudayaan. Retrieved from http://publikasi.data.kemdikbud.go.id/uploadDir/isi C3E61ED4-94A4-4C8E-AFEE091C89F6BF53.pdf

Kotten, N. B. (2005). Upaya Pengembangan Profesionalisme Guru Sekolah Dasar. Jurnal Ilmu Pendidikan (JIP), 12(1). Retrieved from http://journal.um.ac.id/index.php/jip/article/view/83

Majchrzak, A., \& Markus, M. L. (2014). Methods for Policy Research: Taking Socially Responsible Action. SAGE Publications Inc. Retrieved from https://www.worldcat.org/title/methods-for-policyresearch-taking-socially-responsible-action/oclc/829239461 
Matthew B. Miles, A. Michael Huberman, J. S. (2014). Qualitative Data Analysis, A Methods Sourcebook Edition 3. Sage, Arizona State University. Retrieved from https://www.worldcat.org/title/qualitative-data-analysis-a-methodssourcebook/oclc/828333812

Mayang Sari, L. (2008). Perencanaan Strategik Pendidikan. Ihya Arabiah, 4(1), 45-58. Retrieved from https://media.neliti.com/media/publications/265476-perencanaan-strategik-pendidikand05a8b7e.pdf

Moleong, L. J. (2002). Metodologi Penelitian Kualitatif. Bandung: Penerbit PT Remaja Rosdakarya. Retrieved from https://rosda.co.id/pendidikan-keguruan/486-metodologi-penelitiankualitatif-edisi-revisi.html

Nugroho, R. (2009). Public Policy. Jakarta: PT. Elexmedia Komputindo. Retrieved from https://elexmedia.id/detail/produk/PUBLIC\%20POLICY\%206\%20\%20Edisi\%20Revisi/97 $\underline{86020400075}$

Pălăşan, T. (2015). Increased Professionalization, Priority of Teacher Training. Procedia - Social and Behavioral Sciences, 180, 930-936. https://doi.org/10.1016/j.sbspro.2015.02.246

Senduk, J. F. (2008). Pola Pembuatan Kebijakan Pendidikan (Studi Multi Kasus pada Tiga Dinas Pendidikan di Sulawesi Utara). Jurnal Aplikasi Manajemen, 6(1), 145-154. Retrieved from https://jurnaljam.ub.ac.id/index.php/jam/article/download/1866/1391

Setiawan, D., Setiawan, D., \& Sitorus, J. (2017). Urgensi Tuntutan Profesionalisme Dan Harapan Menjadi Guru Berkarakter (Studi Kasus: Sekolah Dasar dan Sekolah Menengah Pertama di Kabupaten Batubara). Jurnal Cakrawala Pendidikan, 36(1), 122-129. https://doi.org/10.21831/cp.v36i1.11382

Supriadi, O. (2009). Pengembangan Profesionalisme Guru Sekolah Dasar. Jurnal Tabulareasa PPS Unimed, 12(1), 27-38. Retrieved from http://ap.fip.um.ac.id/wpcontent/uploads/2015/05/volume-23-no.-630-48.pdf

Taylor, S. J., Bogdan, R., \& Devault, M. L. (2016). Introduction to Qualitative Research Methods, A Guide Book and Resource (4th Edition). John Wiley \& Sons, Inc. Retrieved from https://www.wiley.com/enus/Introduction+to+Qualitative+Research+Methods $\% 3 \mathrm{~A}+\mathrm{A}+$ Guidebook+and+Resource\%2C+ 4th+Edition-p-9781118767214 